\title{
EFEKTIVITAS SEED TAPE DAUN PANDAN LAUT (PANDANUS TECTORIUS) TERHADAP DAYA TUMBUH PAKCOY DAN CAISIM
}

\author{
Effectivity of Seed Tape of Pandan leaves Sea (Pandanus tectorius) against the \\ vigor of Pakcoy and Caisim \\ Denia Faizi Sudiarjo*, Heny Agustin \\ Program Studi Agroekoteknologi Universitas Trilogi-Jakarta \\ $\left.{ }^{*}\right)$ e-mail : deniafaizisudiarjo@gmail.co.m.
}

\begin{abstract}
ABSTRAK
Salah satu teknologi untuk meningkatkan efektivitas penanaman benih berukuran kecil adalah dengan menggunakan seed tape. seed tape ini umumnya terbuat dari gelatin, serat, kaca-kertas (cellophane) atau lapisan larut dalam air. Daun pandan mengandung 83-88\% serat, tetapi belum banyak dimanfaatkan sehingga dapat menjadi alternatif dalam pembuatan seed tape. Penelitian ini dilakukan di Kebun Percobaan Agroekoteknologi, Universitas trilogi mulai Juli-Desember 2018. Bahan yang digunakan adalah $100-150 \mathrm{~cm}$ daun pandan laut yang diperoleh dari pantai Binuangeun Lebak-Banten. Penelitian menggunakan rancangan acak kelompok (RAKL). Faktor pertama adalah jenis seed tape yang tanpa seed tape /penyemaian langsung (S0), seed tape daun pandan laut (S1), dan tisu pita seed tape (S2). Faktor kedua adalah lapisan tapioka yang terdiri dari dua level, yaitu tanpa coating (-) dan dengan coating tapioka (+). Hasil penelitian menunjukkan bahwa pada tahap pertumbuhan awal tanaman, pengobatan seed tape yang diberikan tidak berpengaruh pada indeks vigor, daya tumbuh dan kecepatan pertumbuhan tanaman. Namun, ini menunjukkan efek yang signifikan dari $18 \%$ pada daya pertumbuhan dan $2,58 \% \mathrm{KN} /$ etmal pada kecepatan pertumbuhan tanaman. Pada fase vegetatif, perlakuan seed tape berpengaruh terhadap tinggi dan jumlah daun Pakchoi sampai pengamatan minggu ketiga, tapi tidak mempengaruhi pada pengamatan akhir. Adapun untuk tahap produksi tanaman, perlakuan seed tape berpengaruh pada panjang akar dan berat kering akar tetapi tidakberpengaruh pada berat basah tanaman. Sementara itu, perlakuan seed tape berpengaruh pada panjang akar tetapi tidak berpengaruh pada berat kering akar dan berat basah tanaman caisim.
\end{abstract}

Keywords: pelapis, tapioka, tisu gulung, fase

\begin{abstract}
One technology to increase the effectiveness of planting small-sized seeds is by using seed tape. This tape is generally made of gelatin, fiber, glass-paper (cellophane) or a water soluble layer. Pandan leaves contain $83-88 \%$ fiber content, but it has not been widely used so that it can be an alternative in making seed tape. This research was conducted in the agro-eco-technology experimental farm of the University of Trilogi from July-December 2018. The materials used were 100-150cm sea pandan leaves obtained from Binuangeun Lebak-Banten Beach. The study used a two-factor randomized block design (RBD) method. The first factor is the type of seed tape which is without seed tapeldirect seeding (SO), sea pandan leaf seed tape (S1), and towel tissue seed tape (S2). The second factor is tapioca coating which consists of two levels, i.e. without coating (-) and with tapioca coating (+). The results showed that in the initial growth phase of the plant, the treatment of the seed tape given had no effect on the vigor index, growth power and growth speed of pak choi plants. However, it showed a significant effect of $18 \%$ on growth power and $2.58 \%$ KN/etmal on growth speed on choy sum plants. In the vegetative phase, the seed tape treatment affected the height and number of leaves of the
\end{abstract}


choy sum and pak choi plants until the third week of observation, but this did not affect the choy sum or choy sum plants in the end of the observation. As for the plant production phase, the treatment of seed tape had an effect on root length and root dry weight but not on the fresh weight of pak choi plants. In the meantime, the treatment had an effect on root length but did not influence the root dry weight and fresh weight of the choy sum plant.

Keywords: coating, tapioca, tissue towel, phase

\section{PENDAHULUAN}

Salah satu teknologi untuk memudahkan dan meningkatkan efektivitas dalam menanam benih berukuran kecil adalah dengan penggunaan seed tape. Pemakaian seed tape dapat mencegah penanaman yang terlalu rapat dan memastikan ketepatan dalam penanaman benih (Schindler 1951). Seed Tape atau pita benih umumnya terbuat dari gelatin, serat, kertas kaca (cellophane), atau lapisan yang larut dalam air (Fischer, 1942). Oleh karena itu, kandungan serat dalam daun pandan laut diharapkan dapat digunakan sebagai bahan utama pembuatan seed tape.

Potensi pemanfaatan daun pandan laut yang dilakukan oleh masyarakat sekitar Pantai Binuangeun Lebak-Banten hingga saat ini hanya sebatas sebagai pohon pencegah abrasi atau dijadikan sebagai tikar. Padahal menurut Waluyo (2006) daun pandan laut diketahui memiliki serat yang tinggi yaitu $83-88 \%$. Fazly (2016) menambahkan daun pandan laut juga memiliki kandungan tanin yang dapat digunakan untuk membasmi hama seperti rayap. Oleh karena itu hal ini dapat dijadikan nilai tambahsebagai bahan pestisida alami jika daun pandan laut dibuat sebagai bahan seed tape.

Penggunaan seed tape dari daun pandan laut diharapkan lebih efektif jika dilakukan penambahan pelapisan benih (coating).Pelapisan atau coating merupakan proses pembungkusan benih dengan suatu bahan atau zat tertentu yang berfungsi untuk melindungi benih selama kondisi penyimpanan maupun pada saat perkecambahan. Kuswanto (2003) mengatakan bahwa coating dapat meningkatkan kinerja benih selama perkecambahan. Salah satu bahan coating yang dapat digunakan adalah dengan pemanfaatan tapioka atau ekstrak pati singkong. Menurut Susilawati et. al (2008) kandungan pati dalam singkong mencapai 39\% sehingga dapat dijadikan sebagai bahan pelapis benih. Melalui penelitian ini diharapkan kombinasi pemanfaatan daun pandan laut sebagai seed tape dengan penambahan coating tapioka efektif terhadap pertumbuhan tanaman caisim dan pakcoy.

Penelitian ini bertujuan untuk mengetahui efektivitas penggunaan seed tape daun pandan laut dengan penambahan coating tapioka terhadap daya tumbuh pakcoy dan caisim. 


\section{METODE PENELITIAN}

Penelitian ini dilakukan pada bulan Juli hingga Desember 2018. Pengujian seed tape dilakukan di Kebun Percobaan Agroekoteknologi, Universitas Trilogi, Jakarta. Sementara pengujian indeks tarik dan indeks sobek kertas dilakukan di Balai Besar Pulp dan Kertas, Bandung-Jawa Barat

Bahan yang digunakan sebagai seed tape adalah daun pandan laut dengan warna hijau tua dengan duri yang sudah keras berukuran 100-150 cm yang diperoleh dari Pantai Binuangeun, Lebak-Banten. tisu towel, benih caisim, benih pakcoy, tanah: pupuk kandang (1:1), tapioka dan CMC (carboxyl methylcellulose). Alat yang digunakan dalam penelitian ini adalah panci, kompor gas, ember, blender, pisau, plastik mika, gunting, timbangan, penggaris,micrometer sekrup, pencetak kertas, alat tulis, pisau, gembor, dan oven.

Percobaan ini menggunakan metode Rancangan Acak Kelompok (RAK) dua faktor. Faktor pertama adalah jenis seed tape yang terdiri atas tiga taraf yaitu tanpa seed tape/tanam benih langsung (S0), seed tape dari daun pandan laut (S1) dan seed tape dari tisu towel (S2). Faktor kedua adalah coating tapioca yang terdiri atas dua taraf yaitu tanpa coating (-) dan dengan coating tapioka (+). Setiap perlakuan diulang sebanyak empat kali ulangan sehingga diperoleh 24 unit percobaan pada setiap jenis benih yang diuji. Model rancangan yang digunakan adalah model aditif linier.Analisis ragam dilakukan untuk mengetahui pengaruh perlakuan terhadap tolok ukur yang diamati. Apabila dalam analisis ragam terdapat perbedaan nyata pada taraf $\alpha 5 \%$, maka akan dilakukan uji nilai tengah dengan prosedur Duncan (Gomez \& Gomez 1995).

Daun pandan laut yang berukuran 100-150 cm dipisahkan dari durinya, kemudian dicacah menjadi potongan kecil dan ditimbang hingga mencapai bobot $1 \mathrm{~kg}$.Daun kemudian dimasukan ke dalam panci yang berisi air hingga mendidih.Saat air mendidih, masukan 25 gram $\mathrm{NaOH}$ kedalam pancidan diaduk secara merata. Proses pemasakan dilakukan selama 85 menit dengan api sedang. Daun yang sudah masak kemudian didiamkan selama satu malam (24 jam) selanjutnya dicuci menggunakan air bersih agar terhindar dari bauasam yang dihasilkan oleh $\mathrm{NaOH}$. Daun pandan laut kemudian selama 15 menit agar serat yang dihasilkan lebih halus. Serat lalu dipisahkan dan direndam dengan air bersih kemudian blender kembali selama 10 menit agar serat tampak lebih bersih dan halus.

Hasil bubuk kertas (pulp) yang sudah halus kemudian dicetak dengan menggunakan screen sablondan dikeringkan dengan bantuan sinar matahari. Bubuk kertas (pulp) yang sudah kering akan terbentuk menjadi lembaran kertas yang kemudian 
dipotong dengan lebar $1.5 \mathrm{~cm}$ dan panjang yang disesuaikan. Penggunaan coating tapioka dilakukan dengan cara melarutkan 10 gram tepung tapioka ke dalam 100 ml akuades. Benih di coating satu persatu kemudian susun dengan jarak $10 \mathrm{~cm}$ diatas seed tape dan keringkan selama 24 jam.

\section{HASIL DAN PEMBAHASAN}

\section{a. Penelitian pendahuluan (pembuatan substrat seed tape daun pandan)}

Penelitian pendahuluan dilakukan untuk mendapatkan substrat seed tape dari daun pandan laut agar sesuai dengan yang diharapkan. Proses penghalusan dilakukan sebanyak dua kali agar menghasilkan serat yang terikat satu sama lain (tidak mudah hancur) sehingga homogen. Berdasarkan hasil uji gramatur kertas, diketahui bahwa substrat kertas yang dihasilkan dari daun pandan laut diantaranya memiliki karakteristik ketebalan 0.35-0.69 mm, panjang serat yang tergabung dalam substrat berkisar $0.5-2 \mathrm{~cm}$, indeks tarik kertas $138.9 \mathrm{gf}$ dan indeks sobek kertas $0.67 \mathrm{kN} / \mathrm{m}$ (Gambar 1).

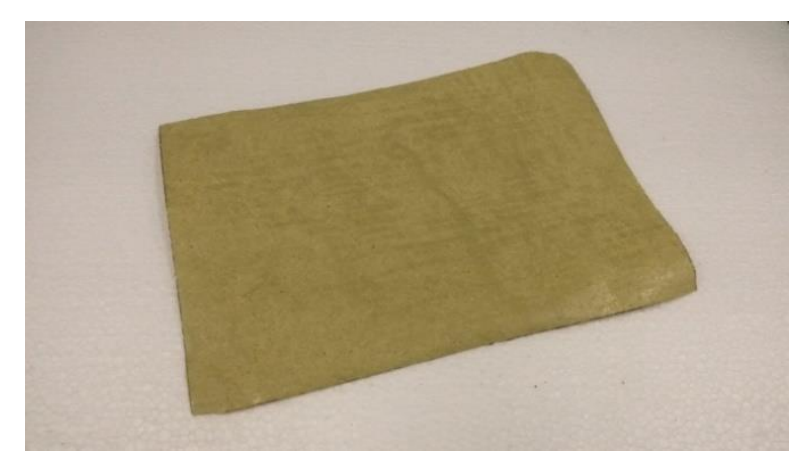

Gambar 1. Substrat kertas daun pandan laut

Berdasarkan hasil dari penelitian pendahuluan diharapkan substrat yang dihasilkan layak digunakan sebagai seed tape. Salah satu syarat untuk membuat seed tape ialah substrat tidak mudah putus, mampu menyerap air dan dapat ditembus oleh akar. Diketahui substrat kertas dari daun pandan laut memiliki panjang serat 0.5-2.0 cm. Panjang serat dipengaruhi oleh kualitas selulosa yang mempunyai peran penting dalam menentukan sifat serat. Serat yang tinggiakan memiliki kemampuan mengikat yang lebih kuat sehingga kualitas kertas semakin baik. Hasil penelitian pendahuluan menunjukan indeks kekuatan tarik kertas 138.9 gf dan indeks kekuatan sobek kertas $0.67 \mathrm{kN} / \mathrm{m}$. Berdasarkan hasil tersebut daun pandan layakdigunakan sebagai seed tape. 


\section{b. Pengaruh Seedtapedaun pandan laut diawal pertumbuhan tanaman}

Pengamatan pertumbuhan awal tanam dilakukan sejak penanaman benih hari pertama hingga hari ke-7 dengan mengukur indeks vigor, daya tumbuh, dan kecepatan tumbuh benih. Hal ini dilakuan untuk mengetahui pengaruh seedtape daun pandan laut terhadap kemampuan tumbuh tanaman pakcoydan caisim.

Hasil penelitian menunjukan bahwa semua perlakuan yang diberikan tidak memberikan pengaruh terhadap seluruh tolok ukur yang diamati pada pertumbuhan awal pakcoy. Hal ini berbeda dengan reaksi yang ditunjukan oleh benih caisim.Perlakuan tanam benih langsung atau tanpa seed tape (S0-) pada benih caisim memiliki daya tumbuh paling tinggi dibandingkan perlakuan lainnya. Perbedaan presentase daya tumbuh tanaman caisim pada perlakuan tanam benih langsung tanpa coating (S0-) memiliki selisih hingga $18 \%$ dengan benih yang diberikan seed tape daun pandan tanpa coating (S1-). Hal ini juga memiliki pengaruh terhadap kecepatan tumbuh benih caisim dimana perlakuan tanpa meggunakan seed tape memiliki nilai paling tinggi dibandingkan dengan perlakuan lainnya dengan selisih presentase $2.58 \% \mathrm{KN} / \mathrm{etmal}$.

Tabel 1. Pengaruh seedtapedaun pandan laut terhadap indeks vigor, daya tumbuh, dan kecepatan tumbuh padabenih pakcoy dan caisim

\begin{tabular}{ccccc}
\hline Benih & Perlakuan & $\begin{array}{c}\text { Index Vigor } \\
(\%)\end{array}$ & $\begin{array}{c}\text { Daya Tumbuh } \\
(\%)\end{array}$ & $\begin{array}{c}\text { Kecepatan tumbuh } \\
(\% \text { KN/Etmal })\end{array}$ \\
\hline \multirow{6}{*}{ Pakcoy } & S0- & $75.00^{\mathrm{a}}$ & $84.00^{\mathrm{a}}$ & $11.99^{\mathrm{a}}$ \\
& S1- & $75.00^{\mathrm{a}}$ & $77.00^{\mathrm{a}}$ & $10.99^{\mathrm{a}}$ \\
& S2- & $70.00^{\mathrm{a}}$ & $81.00^{\mathrm{a}}$ & $11.56^{\mathrm{a}}$ \\
& S0+ & $68.00^{\mathrm{a}}$ & $83.00^{\mathrm{a}}$ & $11.85^{\mathrm{a}}$ \\
& $\mathrm{S} 1+$ & $66.00^{\mathrm{a}}$ & $85.00^{\mathrm{a}}$ & $12.11^{\mathrm{a}}$ \\
& $\mathrm{S} 2+$ & $71.00^{\mathrm{a}}$ & $81.00^{\mathrm{a}}$ & $11.13^{\mathrm{a}}$ \\
\hline \multirow{6}{*}{ Caisim } & S0- & $64.00^{\mathrm{a}}$ & $85.00^{\mathrm{a}}$ & $12.14^{\mathrm{a}}$ \\
& $\mathrm{S} 1-$ & $69.00^{\mathrm{a}}$ & $67.00^{\mathrm{b}}$ & $9.56^{\mathrm{b}}$ \\
& $\mathrm{S} 2-$ & $63.00^{\mathrm{a}}$ & $68.00^{\mathrm{b}}$ & $9.71^{\mathrm{b}}$ \\
& $\mathrm{S} 0+$ & $60.00^{\mathrm{a}}$ & $85.00^{\mathrm{a}}$ & $12.57^{\mathrm{a}}$ \\
& $\mathrm{S} 1+$ & $57.00^{\mathrm{a}}$ & $68.00^{\mathrm{b}}$ & $9.71^{\mathrm{b}}$ \\
& $\mathrm{S} 2+$ & $49.00^{\mathrm{a}}$ & $63.00^{\mathrm{b}}$ & $8.99^{\mathrm{b}}$ \\
\hline
\end{tabular}

Keterangan: Angka-angka pada kolom perlakuan yang diikuti oleh huruf yang sama menunjukkan tidak berbeda dengan DMRT pada taraf 5\%. (S0-) =tanam benih langsung tanpa coating tapioka; $(\mathrm{S} 1-)=$ seed tape daun pandan laut tanpa coatingtapioka; (S2-) =seed tape tisu towel tanpa coating; (S0+) tanam benih langsung + coatingtapioca; $(\mathrm{S} 1+)=$ seed tape daun pandan laut + coatingtapioka; $(\mathrm{S} 2+)=$ seed tape tisu towel + coatingtapioka

Perbedaan pengaruh yang terjadi diantara kedua benih yang diuji diduga karena perbedaan ukuran benih. Secara visual, ukuran benih pakcoy lebih besar dibandingkan dengan ukuran benih caisim sehingga cadangan makananya juga lebih besar. Hal ini dikuatkan dengan pendapat Copeland \& Mc Donald (2001) yang menyatakan bahwa 
cadangan makanan atau endosperm benih yang lebih besar memberikan energy lebih banyak yang digunakan dalam menyediakan nutrisi bagi embrio untuk tumbuh dan berkembang.

Pengujian penggunaan seed tape dengan bahan lain pernah dilakukan oleh Rohmawati (2017) dengan menggunakan serat dari daun sirsak. Hasil penelitiannya menunjukan bahwa ukuran benih yang kecil akan lebih sulit menembus seratdaun dibandingkan dengan benih berukuran besar. Hal ini selaras dengan pengujian yang dilakukan pada benih pakcoy dan caisim diawal masa pertumbuhannya yang tampak pada persentase daya tumbuh dan kecepatan tumbuh benih.

\section{c. Pengaruh Seed tapedaun pandan laut terhadap fase vegetatif tanaman pakcoy dan caisim}

Pengamatan vegetatif tanaman dilakukan di minggu pertama setelah tanam hingga minggu keempat. Variabel yang diamati pada masa vegetatif tanaman ialah tinggi tanaman dan jumlah daun pakcoy dan caisim. Hal ini dilakukan untuk mengetahui sejauh mana efektivitas penggunaan seed tape daun pandan laut pada masa vegetatif keduanya. Pada minggu pertama secara umum rata-rata tinggi tanaman pakcoy dari setiap perlakuan memiliki tinggi $3.3 \mathrm{~cm}$ dan mengalami peningkatan rata-rata mencapai $2.5 \mathrm{~cm}$ pada pengamatan minggu kedua (Gambar 2).

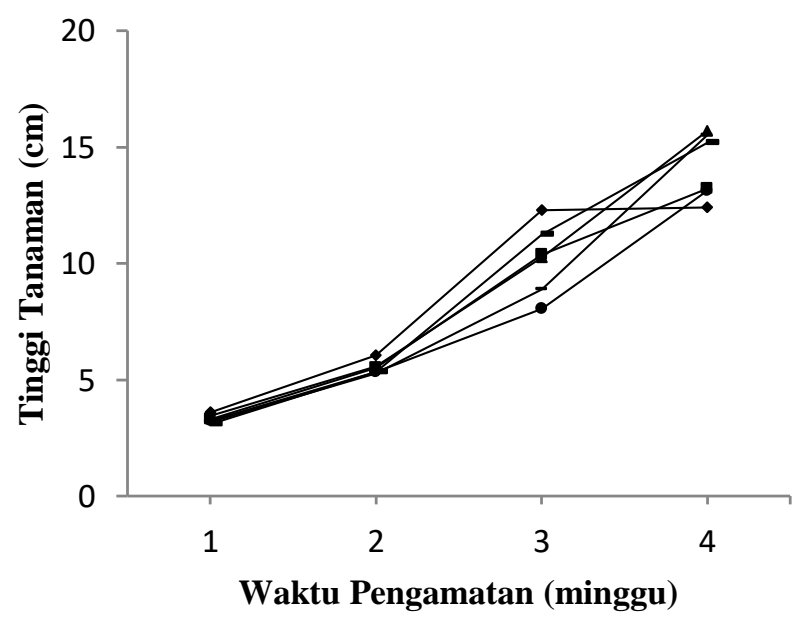
$\longrightarrow$ (S0-) tanam benih langsung tanpa coating
_- (S1-) seed tape daunpandan laut tanpa coating
$\longrightarrow$ (S2-) seed tape tisu towel tanpa coating
$\longrightarrow-(\mathrm{S} 0+)$ tanam benih langsung dengan coating
$-(\mathrm{S} 1+)$ seed tape daun pandan laut dengan coating
$\longrightarrow$ (S2+) seed tape tisu towel dengan coating

Gambar 2. Pengaruh seed tape daun pandan laut terhadap tinggi tanaman pakcoy.

Pada minggu ketiga tampak bahwa perlakuan tanam benih langsung tanpa coating (S0-) menunjukan tinggi tanaman terbaik dibandingkan perlakuan lainnya yaitu $12,30 \mathrm{~cm}$. Akan tetapi pada minggu keempat terjadi perubahan bahwa seluruh perlakuan menunjukan tinggi tanaman yang sama dengan rentang $12.46-15.52 \mathrm{~cm}$. Hal ini 
menunjukan bahwa seluruh perlakuan tidak memberikan pengaruh terhadap tinggi tanaman pakcoy, dengan demikian penggunaan seed tape efektif bagi pertumbuhan tinggi tanaman pakcoy.

Selain tinggi tanaman, jumlah daun juga diamati sebagai salah satu variabel vegetatif. Berdasarkan hasil pengamatan pada jumlah daun menunjukan tidak adanya perbedaan signifikan yang terjadi pada setiap perlakuan hingga pengamatan berakhir. Terlihat pada minggu pertama jumlah daun yang tumbuh rata-rata 1.6 helai. Pada minggu kedua terjadi peningkatan dengan rata-rata 3.45 helai, demikian yang terjadi diminggu ketiga dan keempat dengan rata-rata jumlah helai daun pada akhir pengamatan yaitu 7.32 helai (Gambar 3).

Berdasarkan hasil tinggi tanaman dan jumlah daun pakcoy secara umum menunjukan bahwa penggunaan seed tape yang dimaksudkan untuk mengurangi waktu penananman dan memastikan ketepatan jarak penanaman tidak memberikan pengaruh terhadap tinggi tanaman maka dapat disimpulkan bahwa penggunaan seed tape dianggap efektif bagi pertumbuhan tinggi tanaman pakcoy.

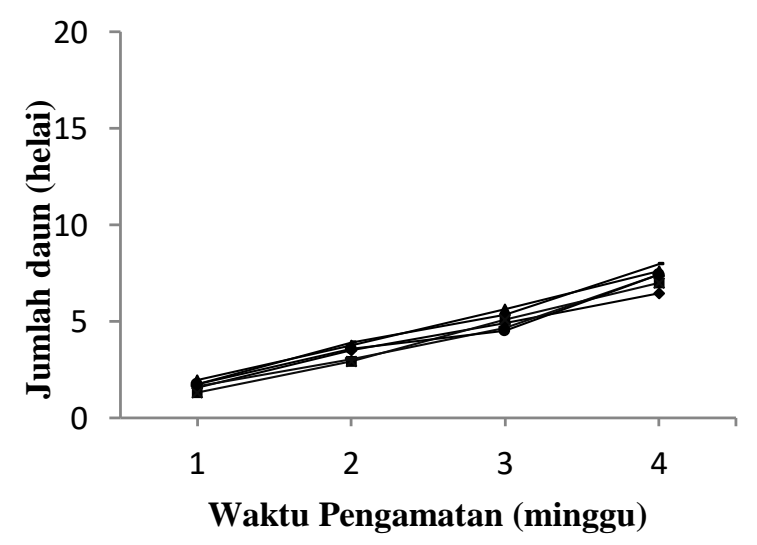
$\longrightarrow$ (S0-) tanam benih langsung tanpa coating
- ( (S1-) seed tape daunpandan laut tanpa coating
$\longrightarrow$ (S2-) seed tape tisu towel tanpa coating
$\longrightarrow$ (S0+) tanam benih langsung dengan coating
- $(\mathrm{S} 1+)$ seed tape daun pandan laut dengan coating
$\longrightarrow(\mathrm{S} 2+)$ seed tape tisu towel dengan coating

Gambar 3. Pengaruh seed tape daun pandan laut jumlah daun tanaman pakcoy.

Pada pertumbuhan tinggi tanaman caisim menunjukan hasil yang cukup mirip dengan pertumbuhan tinggi tanaman pakcoy. Hasil penelitian menunjukan pertumbuhan tinggi tanaman tidak berbeda jauh pada semua perlakuan hingga minggu kedua dengan rentan 3-5.5 $\mathrm{cm}$. Tinggi tanaman mulai meningkat signifikan di minggu ketiga dimana perlakuan tanam benih langsung tanpa coating (S0-) memiliki nilai paling baik dibandingkan semua perlakuan yaitu $14.90 \mathrm{~cm}$ (Gambar 4). 


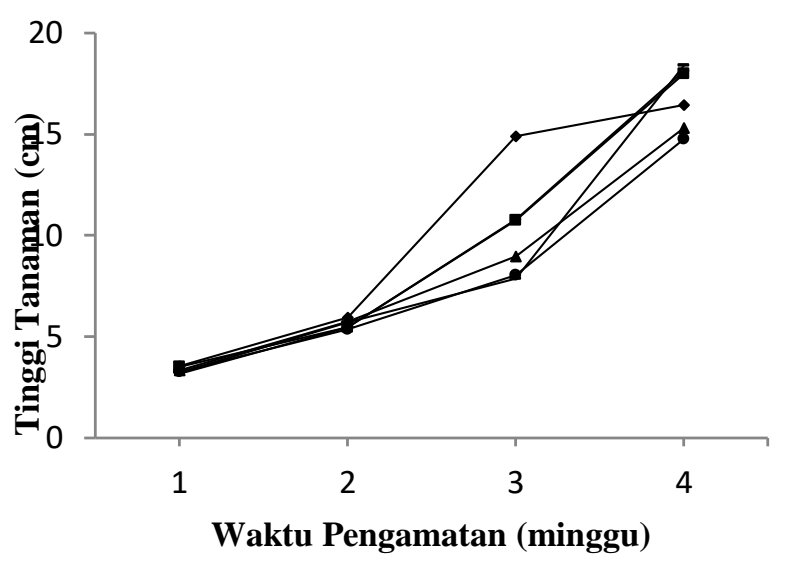

$\longrightarrow$ (S0-) tanam benih langsung tanpa coating

- (S1-) seed tape daunpandan laut tanpa coating

$\longrightarrow$ (S2-) seed tape tisu towel tanpa coating

$\longrightarrow-(\mathrm{S} 0+)$ tanam benih langsung dengan coating

- $(\mathrm{S} 1+)$ seed tape daun pandan laut dengan coating

$\rightarrow$ (S2+) seed tape tisu towel dengan coating

Gambar 4. Pengaruh seed tape daun pandan laut terhadap tinggi tanaman caisim.

Hal ini menjadi menarik ketika perlakuan seed tape daun pandan laut dengan coating mengalami kenaikan tinggi tanaman yang signifikan dengan pertambahan tinggi tanaman mencapai $10 \mathrm{~cm}$ dibandingkan perlakuan lainnya. Seperti halnya yang sudah diketahui bahwa daun pandan laut memiliki kandungan tanin didalamnya. Robinson dalam Sjahid (2018) mengatakan bahwa tanin yang terkondensasi kebanyakan terdiri dari polimer flavonoid dimana flavonoid merupakan senyawa karbon yang terdiri dari dua gugus C6, secara tidak langsung falvonoid ini berperan sebagai zat pengatur tumbuh.Hal ini diduga bahwa flavonoid mulai memberikan efek pada tinggi tanaman pakcoy pada minggu ketiga. Selain itu pemberian coating tapioka diduga dapat membantu pertumbuhan tinggi tanaman. Dapat diketahui bahwa tapioka merupakan hasil ekstrak pati singkong. Rani (2015) mengatakan bahwa pati merupakan senyawa karbohidrat kompleks yang tidak larut dalam air.Kandungan karbohidrat didalam singkong akan diurai menjadi senyawa organik yang dapat di serap tanaman. Dengan perubahan tersebut, kadar karbohidrat akan turun dan senyawa $\mathrm{N}$ yang larut (amonia) akan meningkat. Dengan demlikian, $\mathrm{C} / \mathrm{n}$ semakin rendah dan mendekati $\mathrm{C} / \mathrm{N}$ tanah sehingga dapat menjadi sumber nutrisi bagi tanaman. 


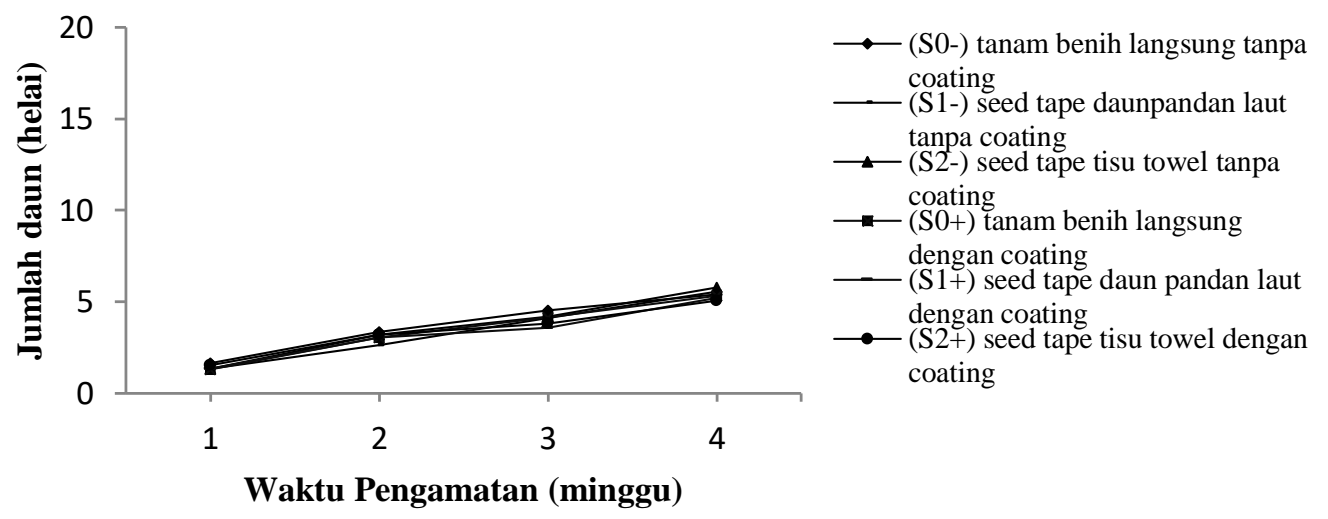

Gambar 5. Pengaruh seed tape daun pandan laut terhadap jumlah daun caisim

Pada jumlah daun caisim menunjukan adanya peningkatanpada setiap minggu hingga minggu pengamatan berakhir. Terlihat tidak ada perbedaan mencolok terhadap pertambahan jumlah daun pada masing-masing perlakuan. Pada minggu pertama daun caisim mulai tumbuh satu hingga dua helai dengan rata-rata jumlah daun dari setiap perlakuan ialah 1.4 helai daun. Minggu kedua, jumlah daun bertambah dua helai dengan rata rata 3.5 helai. Pada minggu ketiga mebhasilkan rataan daun sebanyak 4.0 helai. Pada minggu keempat rerata daun bertambah dengan hasil rataan 5 helai daun dan berdasarkan hasil analisis ragam menunjukan bahwa semua perlakuan tidak memberikan pengaruh terhadap pertambahan jumlah daun caisim diminggu keempat (Gambar 5).

Berdasarkan hasil dari variabel vegetatif yaitu tinggi tanaman dan jumlah daun pada caisim menunjukan bahwa penggunaan seed tape juga tidak memberikan pengaruh terhadap tinggi tanaman maka dari itu dapat disimpulkan bahwa penggunaan seed tape daun pandan laut juga dianggap efektif bagi pertumbuhan vegetatif tanaman caisim.

\section{d. Pengaruh Seed tape terhadap Produksi Tanaman}

Pengamatan variable pada masa vegetatif diharapkan juga selaras dengan hasil produksi tanaman pakcoy dan caisim. Pada tolok ukur panjang akar menunjukan bahwa perlakuan Seed tape daun pandan laut tanpa coating(S1-) memiliki nilai paling tinggi diantara semua perlakuan yaitu $6.72 \mathrm{~cm}$. Hal tersebut juga sama dengan hasil yang ditunjukan pada panjang akar benih caisim dengan nilai (S1-) yaitu $6.92 \mathrm{~cm}$. ). Palupi dan Wiryanto (2008) mengatakan bahwa panjang akar berkaitan dengan ketahanan tanaman pada saat terjadi kekurangan air. Hal ini disebabkan pada saat kekurangan air, tanaman akan memanjangkan akarnya sampai ke lapisan tanah yang memiliki ketersediaan air yang cukup. Hal ini berkaitan dengan bobot kering akar.Tanaman dengan berat kering akar lebih besar pada saat kekurangan air memiliki resistensi terhadap kekurangan air yang lebih besar. Berdasarkan hasil bobot kering pada tanaman menunjukan bahwa 
perlakuan seed tape daun pandan laut tanpa coating(S1-) berpengaruh terhadap bobot kering akar pakcoy tetapi tidak berpengaruh terhadap bobot kering akar tanaman caisim. Hal ini menunjukan bahwa pemberian seed tape daun pandan laut tanpa coating (S0-) bukan satu satunya faktor penyebab tanaman kekurangan air karena berdasarkan bobot segar tanaman menunjukan hasil bahwa semua perlakuan tidak memberikan pengaruh terhadap bobot segar keduanya (Tabel 3).

Tabel 3. Pengaruh seed tapeterhadap panjang akar, bobot kering akar dan bobot segar tanaman caisim dan pakcoy

\begin{tabular}{ccccc}
\hline Benih & Perlakuan & Panjang Akar $(\mathrm{cm})$ & Bobot Kering $(\mathrm{g})$ & Bobot Segar(g) \\
\hline \multirow{6}{*}{ Pakcoy } & S0- & $5.97^{\mathrm{ab}}$ & $0.07^{\mathrm{ab}}$ & $15.51^{\mathrm{a}}$ \\
& S1- & $6.72^{\mathrm{a}}$ & $0.08^{\mathrm{a}}$ & $16.97^{\mathrm{a}}$ \\
& S2- & $5.20^{\mathrm{ab}}$ & $0.07^{\mathrm{ab}}$ & $17.14^{\mathrm{a}}$ \\
& $\mathrm{S} 0+$ & $5.92^{\mathrm{ab}}$ & $0.07^{\mathrm{ab}}$ & $14.96^{\mathrm{a}}$ \\
& $\mathrm{S} 1+$ & $5.22^{\mathrm{ab}}$ & $0.07^{\mathrm{ab}}$ & $14.08^{\mathrm{a}}$ \\
& $\mathrm{S} 2+$ & $4.55^{\mathrm{b}}$ & $0.06^{\mathrm{b}}$ & $15.17^{\mathrm{a}}$ \\
\hline \multirow{6}{*}{ Caisim } & S0- & $5.31^{\mathrm{ab}}$ & $0.07^{\mathrm{a}}$ & $13.38^{\mathrm{a}}$ \\
& $\mathrm{S} 1-$ & $6.95^{\mathrm{a}}$ & $0.06^{\mathrm{a}}$ & $12.35^{\mathrm{a}}$ \\
& $\mathrm{S} 2-$ & $5.40^{\mathrm{ab}}$ & $0.07^{\mathrm{a}}$ & $15.08^{\mathrm{a}}$ \\
& $\mathrm{S} 0+$ & $6.00^{\mathrm{ab}}$ & $0.05^{\mathrm{a}}$ & $13.29^{\mathrm{a}}$ \\
& $\mathrm{S} 1+$ & $5.40^{\mathrm{ab}}$ & $0.06^{\mathrm{a}}$ & $13.26^{\mathrm{a}}$ \\
& $\mathrm{S} 2+$ & $4.80^{\mathrm{b}}$ & $0.04^{\mathrm{a}}$ & $14.86^{\mathrm{a}}$ \\
\hline
\end{tabular}

Keterangan: angka-angka pada kolom perlakuan yang diikuti oleh huruf yang sama menunjukkan tidak berbeda dengan DMRT pada taraf $5 \%$.

Secara umum dapat disimpulkan bahwa perlakuan yang diberikan tidak mempengaruhi hasil produksi tanaman pakcoy maupun caisim. Hal ini menunjukan bahwa penggunaan seed tape daun pandan laut aman bagi produksi tanaman keduanya, dengan demikian pemberian seed tape daun pandan laut efektif digunakan hingga tahap produksi.

Berdasarkan tolok ukur yang telah diamati pada ketiga fase pengamatan yaitu fase awal masa pertumbuhan, fase vegetatif dan fase produksi dengan tolok ukur yang diamati yaitu indeks vigor (\%), daya tumbuh (\%), kecepatan tumbuh (\%), tinggi tanaman $(\mathrm{cm})$, jumlah daun (helai), panjang akar $(\mathrm{cm})$, bobot kering akar $(\mathrm{g})$ dan bobot segar $(\mathrm{g})$, dapat disimpulkan bahwa secara keseluruhan penggunaan seed tape daun pandan laut efektif terhadap daya tumbuh tanaman pakcoy maupun caisim hingga tanaman tersebut berproduksi. 


\section{KESIMPULAN}

\section{Kesimpulan}

Berdasarkan seluruh tolok ukur yang diamati, dapat disimpulkan bahwa penggunaan seed tape dari daun pandan laut efektif terhadap daya tumbuh tanaman pakcoy dan caisim.

\section{Saran}

Pengujian pemberian seed tape daun pandan laut hanya dilakuan pada benih pakcoy dan caisim. Maka dari itu perlu adanya penelitian lebih lanjut padapemberian seed tape daun pandan laut terhadap benih lain.

\section{DAFTAR PUSTAKA}

Copeland, L.O., M.B. Mc Donald. 2001. Principle of Seed Science and Technology. Chapman and Hall. New York, USA.

Fazly.M., Harianto. I., Laksana. M., 2016.Potensi Ekstrak Daun Pandan Laut (Pandanus tectorius) dari Sepanjang Pantai Lebak Selatan Banten sebagai Anti Rayap. SMAN 1 Malingping, Banten

Fischer A.C., penemu; United States. 1942 May 5. Seed tape. Patent United States US 119210.

Palupi ER, Dedy Wiryanto Y. 2008. Kajian karakter Toleransi Cekaman Kekeringan Pada Empat genotip bibit kelapa sawit. Bul Agron.

Rina D. 2015.Manfaat unsur NPK bagi tanaman. Litbang Pertanian. Kalimantan Timur.

Rohmawati.A. 2017.Pemanfaatan Serat Daun Sirsak Sebagai Kemasan Benih Bentuk Pita dan Aplikasi Bakteri Probiotik Untuk Meningkatkan Vigor Benih.IPB.

Sadjad, S., Murniati, E., Ilyas, S. 1999. Parameter Pengujian Vigor Benih, Dari Komparatif ke Simulatif. PT Grasindo.

Schindler G.A., penemu; United States.1951 Oct 16. Seed tape. Patent United States US 66362.

Susilawati., Nurdjanah S., Putri S., 2008. Karakteristik Sifat Fisik dan Kimia Ubi Kayu (Manihot esculenta) Berdasarkan Lokasi Penanaman dan Umur Panen Berbeda.UNILA, Lampung. 